\title{
Kecerdasan Emosional dalam Kepemimpinan Pendidikan
}

\author{
Antonius Remigius Abi \\ Akademi Manajemen Informatika Komputer UNIVERSAL, Medan, Sumatera Utara \\ antoniusremigus@gmail.com
}

\begin{abstract}
Educational leadership that has the criterion of emotional quotient is the leader with the ability to influence the educational community through self-awareness and self-management. This ability helps school leaders to understand the society. In other words, the leader has the social awareness and skill management. It is the skill to interact with the shcool community their wants. In addition, the school leaders are required to be honest to their selves and the whole educational community for their building of self strength, self-conscience, honor, and responsibility to the whole school community. To conclude that the cooperation between leaders and society (social community) the goal of the education will be achieved.
\end{abstract}

Key Word: emotional intelligence; education; educational leadership; quotient

\begin{abstract}
Abstrak: Kepemimpinan pendidikan yang memiliki kriteria quatition emosional adalah kepemimpinan dengan kemampuan untuk mempengaruhi komunitas pendidikan melalui kesadaran diri dan manajemen diri. Kemampuan ini membantu para pemimpin sekolah untuk memahami masyarakat. Dengan kata lain, pemimpin memiliki kesadaran sosial dan manajemen keterampilan. Ini adalah keterampilan untuk berinteraksi dengan komunitas shcool yang mereka inginkan. Selain itu, para pemimpin sekolah dituntut untuk jujur pada diri mereka sendiri dan seluruh komunitas pendidikan untuk membangun kekuatan diri, hati nurani, kehormatan, dan tanggung jawab mereka kepada seluruh komunitas sekolah. Untuk menyimpulkan bahwa kerja sama antara para pemimpin dan masyarakat (komunitas sosial) tujuan pendidikan akan tercapai.
\end{abstract}

Kata Kunci: kecerdasan; kecerdasan emosional; pendidikan; kepepemimpinan pendidikan

\section{PENDAHULUAN}

Pada masa sekarang ini (abad ke-21) yang dibutuhkan lembaga pendidikan sekolah baik tingkat dasar, tingkat menengah maupun tingkat tinggi adalah pemimpin yang menumbuhkan resonansi emosi yang membuat semua warga sekolah tumbuh dan berkembang. Kepemimpinan pendidikan yang menumbuhkan resonansi emosi dapat membawa sinergitas kinerja warga sekolah mencapai prestasi bersama. Artinya kepemimpinan pendidikan yang cerdas emosi bukan kepemimpinan rasional, linear yang dominan, dan berpijak pada peraturan-peraturan sepihak dan kaku.

Kepemimpinan pendidikan yang memiliki kecerdasan emosional (EQ) mampu menciptakan iklim emosi yang menumbuhkan inovasi, kreatif, dan relasi yang hangat dengan warga sekolah. Ia tetap memberi inspirasi, gairah, dan antusiasme serta motivasi dan komitmen kepada warganya. Artinya pemimpin yang memiliki EQ dapat 
memancarkan energi positif, yang membuat warganya menjadi terbuka terhadap diri dan orang lain.

Pemimpin pendidikan yang memiliki EQ dapat menciptakan situasi/keadaan sekolah tidak mencekam tetapi lebih fleksibel. Adanya komunikasi yang bersahabat di antara pimpinan dan para guru saat duduk bersama, ada kelakar dan kegembiraan. Komunikasi siswa dengan guru menjadi lebih fleksibel sehingga ada tumbuh suasana keakraban. Komunikasi pimpinan dengan warganya juga akan lebih ramah, sehingga tercipta keterbukaan antara warga dengan pimpinannya, pegawai dengan pimpinan maupun pegawai dengan para pembantunya serta siswa. Komunikasi yang terbuka, akrab dan bersahabat di antara para warga sekolah (pimpinan, siswa, guru dan pegawai) membuat keadaan para warga sekolah tampil lebih percaya diri.

Pimpinan sekolah memiliki 'radar' sosial, kompetensi untuk memahami warga sekolah, kemauan untuk mengembangkan warga sekolah, memiliki orientasi pelayanan, menghargai keragaman, memiliki kesadaran politik, persuasif, mampu berkomunikasi, memiliki kemampuan dalam manajemen konflik, terbuka pada perubahan, kolaborasi dan kooperatif serta memiliki kemampuan tim. Dengan karakter positif yang dimiliki, warga sekolah terbantu mengembangkan potensi-potensi yang positif yang ada dalam diri mereka. Jadi perkembangan potensi positif warga sekolah sangat ditentukan oleh pemimpinnya sebaga penggerak dan penentu arah. Sebab pemimpin pendidikan (sekolah) adalah seseorang yang menentukan titik pusat dan irama suatu sekolah. ${ }^{1}$ Ia adalah seorang yang menjadi tumpuan utama dalam mencari kepastian dan kejelasan ketika warga sekolah menghadapi ketidakpastian dan ketika suatu tugas harus dilakukan.

Pemimpin merupakan faktor penentu bagi hidup, berkembang, juga matinya organisasi, baik di sektor publik maupun bisnis, di tingkat puncak, menengah dan bawah, yang dimiliki negara maupun swasta baik itu menyangkut kepemimpinan tunggal ataupun kolektif". ${ }^{2}$ Artinya posisi dan peran pemimpin pendidikan sangat strategis memimpin improvisasi kinerja warga sekolah sehingga mencapai puncak prestasi yang optimal. UU Sisdiknas N0. 20 dan PP N0. 19 tahun 2005 mengutarakan bahwa pemimpin pendidikan yang kompeten harus memiliki pengetahuan, ketrampilan, sikap, performance dan etika kerja sesuai dengan tugas dan tanggung jawabnya sebagai kepala sekolah. ${ }^{3}$

\section{METODE}

Metode penulisan menggunakan metode library research. Penulisan artikel ini bertujuan untuk mengetahui peran kecerdasan emosional dalam kepemimpinan pendidikan di lembaga sekolah.

\footnotetext{
${ }^{1}$ Wahjosumidjo, Kepemimpinan Kepala Sekolah. Tinjauan Teoretik dan Permasalahannya (Jakarta: RajaGrafindo Persada, 2005), 82.

${ }^{2}$ Faisal Afiff, Melacak Pemikiran Strategik (Jakarta: Paramadina, 2003), 55

${ }^{3}$ Yustisia, Standar Kompetensi Kepala Sekolah, TK, SD, SMP, SMA, SMK \& SLB (Yogyakarta: Pustaka Yustisia, 2007), 136
} 


\section{Kecerdasan Emosional}

Emotional Intelligence (EI) adalah istilah dalam bahasa Inggris yang artinya kecerdasan emosional. Istilah ini digunakan dalam suatu organisasi untuk menilai sumber daya manusia di samping intelektualnya. Penelitian ini memberi nilai kecerdasan emosional yang muncul baik dari pemikiran intelektual maupun pekerjaan hati manusia, (bdk. Cooper, dkk, 2002:xiv) Karena itu, nilai kecerdasan emosional bukanlah trik-trik penjualan, bukan memakai topeng kemunafikan bukan pula penggunaan psikologi untuk mengendalikan maupun memanipulasi seseorang.

Nilai kecerdasan emosional bersumber dari pola pikir kecerdasan emosional (EI). Cara kerja kecerdasan emosional (EI) adalah berpikir assosiatif dan sikap integralistik. Berpikir assosiatif berhubungan dengan kemampuan seseorang untuk menyadari diri dan memotivasi diri sekaligus menyadari rasa peduli pada orang lain (empati). Sikap integralistik merupakan kemampuan berpikir stimulus-respon sebagai dasar kemampuan untuk menentukan sikap. ${ }^{4}$ Artinya kepemimpinan yang memiliki EI mampu berpikir assosiatif dan memiliki sikap integralistik. Dalam hal ini kepemimpinan pendidikan perlu memiliki kemampuan berpikir assosiatif dan sikap integralistik.

Kecerdasan emosional adalah kemampuan khusus untuk membaca perasaan terdalam orang-orang yang dihadapi dengan maksud mengatasi relasi secara efektif dan strategis. ${ }^{5}$ Kemampuan khusus yang dimaksud di sini adalah kemampuan pemimpin pendidikan mengenali perasaan diri, kemudian mengelolanya serta mengenali perasaan orang lain dan mengelolanya secara efektif.

Kecerdasan emosional adalah kemampuan untuk memotivasi diri sendiri dan bertahan menghadapi frustrasi; mengendalikan dorongan hati dan tidak melebih-lebihkan kesenangan; mengatur suasana hati dan menjaga agar beban stres tidak melumpuhkan kemampuan berpikir; berempati dan berdoa. ${ }^{6}$ Kemampuan di sini adalah mengetahui dan menangani perasaannya sendiri dengan baik dan mampu membaca serta menghadapi perasaan orang lain (bawahan) dengan efektif. Pemimpin yang memiliki seni memimpin, mampu mengendalikan diri dan orang lain secara resonans serta memiliki pikiran yang jernih. Kendali diri-emosi tidak sama dengan kendali berlebihan (overcontrol), penyangkalan semua perasaan dan spontanitas tetapi kendali diri berarti seseorang (pemimpin) memiliki pilihan bagaimana mengungkapkan perasaannya. Sebab pengendalian diri yang berlebihan mendatangkan kerugian baik bagi fisik maupun mental. Apabila penekanan emosi berlebihan, kemampuan berpikir bisa rusak, berakibat pada rendahnya kinerja intelektual dan terganggunya interaksi sosial. Jadi pengendalian diri berarti menjaga agar emosi dan impuls yang merusak tetap terkendali.

${ }^{4}$ Belferik Manullang, Taste For Leadership, Kepemimpinan Pendidikan IQ-EQ-SQ. (Medan: Program Pascasarjana, 2004), 10

${ }^{5}$ R. Henry Meyer, Manajemen Dengan Kecerdasan Emosional (Bandung: Nuansa, 2007), 27

${ }^{6}$ Daniel Goleman, Kecerdasan Emosional. (Jakarta: Gramedia Pustaka Utama, 2004), 45. 


\section{Kepemimpinan Pendidikan}

Kepemimpinan merupakan suatu hal yang sangat penting dalam sebuah organisasi. John Price Jones mengatakan organization is a united group of people working for a common goal, under common leadership and with the proper tools, dalam. ${ }^{7}$ Organisasi adalah sekelompok orang yang bersatupadu bekerja untuk suatu tujuan bersama di bawah kepemimpinan bersama, dengan alat-alat yang tepat. Kepemimpinan pendidikan bertujuan untuk meningkatkan kinerja para guru, staf maupun kualitas dari para siswa berdasarkan kecerdasan emosi. Prilaku pemimpin pendidikan dapat mendorong kinerja para guru dengan menunjukkan rasa bersahabat, dekat dan penuh pertimbangan terhadap para guru, sebagai individu dan sebagai kelompok. ${ }^{8}$ Kepemimpinan pendidikan adalah proses mempengaruhi kegiatan seseorang atau kelompok dalam usaha-usaha ke arah pencapai tujuan dalam situasi tertentu. ${ }^{9}$ Kepemimpinan tersebut meliputi perilaku baik verbal maupun nonverbal dalam komunikasi dengan para guru (warga sekolah) untuk pembuatan keputusan serta pelaksanaan keputusan.

Tannembaum, dkk, mengatakan, Leadership is interpersonal influence exercised in a situation and directed, through the communication process, toward the attainment of a specified goal or goals, dalam. ${ }^{10}$ Kepemimpinan adalah pengaruh antar pribadi, dilatih dalam situasi dan diarahkan melalui proses komunikasi untuk mencapai tujuan atau tujuantujuan khusus. Definisi ini mengandung beberapa hal yakni pertama, di dalam satu fenomena kelompok melibatkan interaksi antara dua orang atau lebih. Kedua, proses mempengaruhi warga sekolah secara sengaja untuk mencapai satu tujuan tertentu. Dalam konteks ini baik proses interaksi maupun proses mempengaruhi warganya hanya akan berdampak posistif apabila dilandasi oleh kesadaran diri dan kesadaran sosial dari pemimpin.

Menurut Soetopo dan Soemanto yang dikutip Syafarudin, kepemimpinan pendidikan adalah kemampuan untuk mempengaruhi dan menggerakkan orang lain untuk mencapai tujuan pendidikan secara bebas dan sukarela. ${ }^{11}$ Pendapat lain, Dirawat, dkk., kepemimpinan pendidikan adalah sebagai suatu kemampuan dan proses mempengaruhi, mengkoordinir dan menggerakkan orang-orang lain yang ada dalam hubungan dengan pengembangan ilmu pendidikan dan pelaksanakan pendidikan dan pengajaran agar supaya tercapai tujuan secara efektif. ${ }^{12}$

\footnotetext{
2006), 1 .

${ }^{7}$ Sutarto, Dasar-Dasar Kepemimpinan Administrasi (Yogyakarta: Gajah Mada University Press,

${ }^{8}$ E Mulyasa, Menjadi Kepala Sekolah Profesional (Bandung: Remaja Rosdakarya, 2005), 107

${ }^{9}$ Bambang R. Sutikno, The Power of Empathy In Leadership (Jakarta: Gramedia Pustaka Utama, 2007), 254

${ }^{10}$ Wahjosumidjo, Kepemimpinan Kepala Sekolah. Tinjauan Teoretik dan Permasalahannya, 17

${ }^{11}$ Syafaruddin, Kepemimpinan Pendidikan, Akuntabilitas Pimpinan Pendidikan dalam Konteks Otonomi Daerah (Jakarta: PT. Ciputat Press, 2010), 85

${ }^{12}$ Dirawat, dkk., Pengantar Kepemimpinan Pendidikan (Surabaya: Usaha Nasional, 1986), 33
} 
Berdasarkan pendapat di atas disimpulkan bahwa kepemimpinan pendidikan mengandung unsur-unsur, yaitu proses mempengaruhi warganya, menggerakkan orang lain untuk mengikuti ide pimpinan, berlangsung dalam organisasi sekolah, dan tujuan akhir untuk mencapai tujuan secara efktif dan efisien.

\section{Kecerdasan Emosional dalam Kepemimpinan Pendidikan}

Kecerdasan emosional dalam kepemimpinan adalah kemampuan pemimpin dalam berinteraksi dengan warga sekolah (guru-guru, tenaga administrasi dan para siswa) secara lebih komunikatif, fleksibel, bersahabat dan luwes. Atau Kecerdasan emosional dalam kepemimpinan pendidikan adalah kemampuan pemimpin sekolah mempengaruhi warga sekolah melalui self awareness dan self manajement sehingga dapat memahami orang lain (social awareness) kemudian secara trampil mengelolanya (skill manajement) - seni berelasi dengan warga sekolah agar dapat menerjemahkan keinginan-keinginan warga sekolah dengan menekankan tujuan dan sasaran organisasi sekolah yang mau dicapai melalui kerja sama pimpinan dan warga sekolah serta dukungan semua pihak.

Pemimpin pendidikan yang cerdas emosi jujur pada dirinya dan jujur pada warga sekolah guna membangun kekuatan pribadi dengan cara mendengarkan suara hati, hormat dan bertanggung jawab terhadap warga sekolah. Dengan demikian, penulis menyimpulkan bahwa kepemimpinan pendidikan yang cerdas emosional adalah kemampuan pemimpin menyadari diri dan mengendalikan diri serta mempengaruhi warga sekolah melalui empati serta interaksi yang terbuka untuk meningkatkan kinerja seluruh warga sekolah.

\section{PEMBAHASAN}

Berdasarkan kajian pada teori, penulis mendefinisikan kecerdasan emosional kepemimpinan pendidikan adalah kemampuan pemimpin dalam menyadari diri, kemudian mengendalikannya serta merasa empati terhadap warganya kemudian menggunakan pendekatan terhadap bawahan secara persuasif (seni mempengaruhi warganya). Jadi, seorang pemimpin pendidikan yang cerdas emosional memiliki lima unsur yakni kesadaran diri, pengendalian diri, motivasi, empati dan seni mempengaruhi warganya.

\section{Kesadaran diri}

Pemimpin pendidikan yang cerdas emosional mampu mengambil keputusan dengan arif dan bijaksana. Keputusan ini didasarkan atas pertimbangan yang komprehensif; tidak hanya didasarkan pada aturan-aturan resmi, akan tetapi ada pertimbangan-pertimbangan lain didasarkan pada "kata hati" yang lebih menguntungkan semua pihak. Keputusan dengan "kata hati" dimaksud, yakni keputusan didasarkan pada pertimbangan nilai-nilai edukatif (pedagogis), kemanusiaan, kemasyarakatan, budaya, moral dan religius yang dimiliki oleh pemimpin. Ia mengambil keputusan lebih memperhatikan pada nilai pedagogis (edukatif) yang ada pada dirinya (kata hatinya) yaitu mutu proses pembelajaran dan akuntabilitas mutu pengikutnya, sehingga mengharuskan mereka memiliki rencana pembelajaran yang matang. 
Ia bukanlah pribadi yang otoriter melainkan terbuka, dengan melakukan umpan balik, berbagi pengalaman dengan pengikutnya untuk membangun suatu keputusan bersama. Ia mau belajar dari pengalaman warganya dan memiliki kesadaran diri dengan menyelaraskan keputusan-keputusan terhadap nilai-nilai yang paling penting untuk dicapai dari mutu proses kegiatan bersama di sekolah. Kesadaran diri menawarkan pedoman yang pasti untuk menjaga keputusan-keputusan karier kita tetap selaras dengan nilai-nilai yang paling dalam. $^{13}$

\section{Pengendalian Diri}

Pemimpin pendidikan yang memiliki cerdas emosional terlebih dahulu melakukan pengendalian diri dengan cara mencoba bersedia menerima alasan mengapa pengikutnya melakukan suatu pelanggaran peraturan tertentu. Ia meredam emosinya dengan cara berdialog, bersedia mendengarkan keluhan pengikutnya. Dalam hal ini tergambar bahwa ia tidak gampang meledak-ledak emosinya. Ia tidak mudah terpancing emosinya dari tindakan atau perlakuan pengikutnya walaupun tidak sesuai dengan yang diinginkannya.

Dalam hal ini juga dipahami bahwa pemimpin pendidikan yang mengendalikan diri ini tidak hanya meredam rasa tekanan atau gejolak emosinya tetapi juga berarti dia berusaha menghayati suatu emosi yang dapat menyenangkan orang lain. Pengendalian diri tidak hanya berarti meredam rasa tertekan atau menahan gejolak emosi, tapi juga berarti berusaha menghayati suatu emosi termasuk yang tidak menyenangkan. ${ }^{14}$

\section{Motivasi}

Dalam konteks pemimpin pendidikan motivasi lebih dekat dengan usaha kerja keras yang mendorongnya untuk berprilaku. Dorongan tersebut menggerakkannya untuk berupaya mencapai cita-citanya. Karena itu ia mencari alternatif solusi untuk melakukan segala hal yang berhubungan dengan harapan yang diinginkannya. Dalam pada itu, seorang pemimpin selalu berkeinginan (tetap semangat) untuk mengerjakan sesuatu mengatasi masalah-masalah sekecil apapun, demi peningkatan kinerja pengikutnya, maupun proses pembelajaran di sekolah. Bahkan lebih dari itu dapat dikatakan ia tidak pernah patah semangat walaupun kadang kala tidak selalu disetujui seluruh pengikutnya, khusus ide-ide yang diajukan demi kemajuan pendidikan sekolah.

\section{Empati}

Pemimpin pendidikan yang empati memiliki kepekaan terhadap kebutuhan pengikutnya atau kepentingan pengikutnya. Ia membantu pengikutnya berdasarkan perspektif warganya, dengan memperhatikan isyarat-isyarat perasaan mereka tanpa mengorbankan kepentingan sekolah. Ia mampu memahami atau mengindra perasaan dan perspektif pengikutnya serta aktif menunjukkan keputusan yang berhubungan dengan kepentingan mereka dan kepentingan sekolah. Jadi, ia memiliki kecakapan-kecakapan memahami

\footnotetext{
${ }^{13}$ Goleman, Kecerdasan Emosional, 92

${ }^{14}$ Ibid., 127
} 
pengikutnya berorientasi melayani mereka dan memanfaatkan keragaman mereka untuk kemajuan organisasi sekolah. Ia memperhatikan dan menunjukkan kepekaan serta bersedia membantu sesuai dengan perasaan, perspektif dan kebutuhan mereka.

Ciri pemimpin pendidikan yang berempati, sejalan dengan pendapat di bawah ini, empati adalah mengindra perasaan-perasaan dan perspektif orang lain serta menunjukkan minat aktif terhadap kepentingan-kepentingan mereka. ${ }^{15}$ Senada dengan pendapat tersebut di atas, pemimpin pendidikan yang berempati adalah pemimpin yang tidak saja sepakat tetapi secara mendalam mencoba mengerti orang lain, baik dari segi emosional, maupun intelektual, mencamkan nada suara, bahasa tubuh orang, dan kata-kata. ${ }^{16}$ Kedua pendapat di atas, mengandung makna bahwa pemimpin pendidikan yang mempunyai empati dapat mendengar dengan hati, mata, dan pikiran secara obyektif menggunakan sekaligus semua pancaindra.

\section{Seni Mempengaruhi}

Kepemimpinan pendidikan yang memiliki seni dalam mempengaruhi warganya mempunyai karakter selalu senyum, sopan, low profile, berpakaian rapi, terbuka, percaya serta mau melibatkan mitranya dalam mengambil sebuah keputusan. Ia menerapkan taktik persuasi dalam berinteraksi dengan warganya, misalnya melibatkan mereka dalam menyelesaikan tugas. Tujuannya agar mereka memiliki rasa tanggung jawab bersama. Ia percaya pada mitranya ketika melaksanakan tugas-tugas dan menjalin hubungan dengan semua warga sekolah sehingga mereka merasa dihargai, dihormati dan disukai.

Dengan ini mitra/warga sekolah termotivasi ikut bertanggung jawab dalam mengerjakan tugas pembelajaran di sekolah. Ia berusaha meyakinkan warga sekolah dengan kata-kata yang menyentuh hati, yakni "Andalah yang bisa memajukan sekolah ini. Jika tanpa Anda, maka semua akan sia-sia." Dengan teknik persuasi seperti ini, warga sekolah menyadari bahwa kemajuan sekolah dan masa depan sekolah adalah tanggung jawab seluruh warga sekolah, bukan hanya pemimpin.

Pendekatan pemimpin pendidikan terhadap warga sekolah dengan strategi membangun hubungan rasa saling percaya, terbuka dan mau melibatkan warga dalam melaksanakan tugas demi kepentingan dan kemajuan sekolah adalah ciri kepemimpinan yang tepat. Cara yang dimaksud agar lebih mudah menjalin komunikasi yang positif dengan warga sekolah. Komunikasi yang positif adalah komunikasi yang selalu mengutamakan kebersamaan dan kepentingan umum.

Seni mempengaruhi orang lain adalah mengajak orang lain untuk bertumpu pada nalar dan kenyataan, mengajukan argumentasi atau tindakan dramatis, membangun koalisi dan dukungan di 'belakang layar' dan menekankan informasi lebih penting. ${ }^{17}$

\footnotetext{
${ }^{15}$ Ibid., 119

${ }^{16}$ Sutikno, The Power of Empathy In Leadership, 14

${ }^{17}$ Goleman, Kecerdasan Emosional, 273
} 


\section{KESIMPULAN}

Kesadaran diri pemimpin pendidikan adalah kemampuan untuk mengenali diri, kemudian menilai diri secara akurat dan menumbuhkan rasa percaya diri yang baik. Dengan demikian, ia mampu mengenali, dan menilai warganya berdasarkan fakta dan data yang pada akhirnya membantunya meningkatkan kepercayaan diri warganya dalam menjalankan tugas-tugasnya di sekolah. Pengendalian diri pemimpin pendidikan yang cukup baik dapat menolongnya untuk tetap berpikir jernih dan positif dalam menghadapi tekanan, tepat waktu, cermat dalam bekerja, disiplin diri dan teliti dalam menjalankan tanggung jawab, bersikap luwes, kesediaan menerima informasi baru. Ia tetap memiliki dorongan untuk meraih prestasi sekolah, memiliki sikap optimis dan inisiatif. Empati seorang pemimpin pendidikan dapat mendorongnya untuk mendengarkan dengan baik, merasakan dan menghayati kebutuhan dari perspektif warganya. Terbuka untuk mengembangkan kemampuan warga sekolah, serta memberi pelayanan setulus hati, dan menghargai keberbedaan, tanggap terhadap situasi sosial warganya maupun mitranya dari pemerintah. Seni mempengaruhi warganya dapat menciptakan komunikasi yang baik, mampu mengelola konflik secara tepat, menjadi teladan, dan mampu membangun tim kerja dengan warga sekolah secara baik karena ada kerja sama dan semangat dari warga sekolah sehingga dapat memberi inspirasi bagi warga sekolah dalam kepemimpinannya.

Jadi, kecerdasan emosional dalam kepemimpinan pendidikan adalah kemampuan pemimpin sekolah menyadari dirinya melalui penilaian diri secara mendalam dan membangkitkan rasa percaya diri kemudian mengelolanya melalui integritas dan kesungguhan hati, inovasi dan penyesuaian diri, memiliki motivasi serta komitmen yang tinggi, inisiatif, dan optimisme serta rasa empati sehingga menciptakan hubungan yang harmonis dengan sesama warga sekolah.

\section{REFERENSI}

Afiff, Faisal. 2003. Melacak Pemikiran Strategik. Jakarta: Paramadina

Cooper, Robert. K. dkk. 2002. Executive EQ. Kecerdasan Emosional dalam

Kepemimpinan dan Organisasi. Alih Bahasa, Alex Tri Kantjono Widodo. Jakarta:

Gramedia Pustaka Utama.

Dirawat, dkk. 1986. Pengantar Kepemimpinan Pendidikan. Surabaya: Usaha Nasional Goleman, Daniel. 2004. Emotional Intelligence. Kecerdasan Emosional. Alih Bahasa: T. Hermaya. Jakarta: Gramedia Pustaka Utama 2005. Working With Emotional Intlligence. Kecerdasan Emosi untuk

Mencapai Puncak Prestasi. Alih Bahasa: Alex Tri Kantjono Widodo. Jakarta:

Gramedia Pustaka Utama.

Manullang, Belferik. 2004. Taste For Leadership, Kepemimpinan Pendidikan IQ-EQ-SQ. Medan: Program Pascasarjana

Mulyasa. E. 2005. Menjadi Kepala Sekolah Profesional. Bandung: Remaja Rosdakarya Meyer. R. Henry. 2007. Managing with Emotional Intelligence: It Takes Two to Tango.

Manajemen Dengan Kecerdasan Emosional. Alih Bahasa: Munir. Bandung: Nuansa. Sutarto. 2006. Dasar-Dasar Kepemimpinan Administrasi. Yogyakarta: Gajah Mada University Press 
Sutikno, Bambang. R. 2007. The Power of Empathy In Leadership. Jakarta: Gramedia Pustaka Utama

Syafaruddin. 2010. Kepemimpinan Pendidikan, Akuntabilitas Pimpinan Pendidikan dalam Konteks Otonomi Daerah. Jakarta: PT. Ciputat Press

Wahjosumidjo. (2005). Kepemimpinan Kepala Sekolah. Tinjauan Teoretik dan Permasalahannya. Jakarka: RajaGrafindo Persada.

Yustisia. 2007. Standar Kompetensi Kepala Sekolah, TK, SD, SMP, SMA, SMK \& SLB. Yogyakarta: Pustaka Yustisia. 